\begin{tabular}{|c|c|c|}
\hline & Int.J.Curr.Microbiol.App.Sci (2017) 6(6): 1914-1921 & \\
\hline EXCELLENT & $\begin{array}{l}\text { International Journal of Current Microbiology and Applied Sciences } \\
\text { ISSN: 2319-7706 Volume } 6 \text { Number } 6 \text { (2017) pp. 1914-1921 } \\
\text { Journal homepage: } \underline{\text { http://www.ijcmas.com }}\end{array}$ & 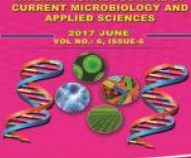 \\
\hline $\begin{array}{l}\text { EXCELLENT } \\
\text { PUBLISHERS }\end{array}$ & & \\
\hline
\end{tabular}

Original Research Article https://doi.org/10.20546/ijcmas.2017.606.223

\title{
Euryale ferox (Salisb): Promising Aquatic Food Crop of Eastern Indo Gangetic Plains
}

\author{
B.P. Bhatt, V.K. Gupta, Lokendra Kumar, Indu Shekhar Singh* and Bikash Sarkar \\ ICAR Research Complex for Eastern Region, P.O. Bihar Veterinary College \\ ICAR Parisar, Patna- 800 014, India \\ *Corresponding author
}

\section{A B S T R A C T}

Keywords

Euryale ferox, Aquatic ecosystem, Sustainability, EIGP.

Article Info

Accepted:

23 May 2017

Available Online:

10 June 2017
Fox nut (Euryale ferox Salisb,) is an important non-cereal staple aquatic food crop, commercially cultivated in Eastern Indo-Gangetic Plains (EIGP) and thereby supports the livelihood of more than 2 million resource poor farmers. Its traditional method of cultivation and post-harvest handling depends on wisdom of the farmers, particularly the fishermen communities. Shrinking water bodies are major threat for sustaining the production potential in traditional methods of cultivation. However, technology has been developed and standardized for cultivation of Fox nut in cropping system mode at 0.30$0.40 \mathrm{~m}$ shallow depth of water with average productivity of 2.5-3.0 t/ha compared to 1.4$1.6 \mathrm{t} / \mathrm{ha}$ in traditional methods of cultivation. After harvest of Fox nut, water chestnut (Trapa natans L.), green fodder/wheat and/or pulses could be cultivated from a same field, thereby, improving the cropping intensity from 100\% to more than 200\%. Fox nut has been found as a rich source of carbohydrates, protein, energy and nutrients. Popped nuts are also rich in amino acids, particularly glutamic acid, arginine, leucine and valine. Mechanization of cultivation and post-harvest management including diversification in aquatic crops is urgently required for sustainability of fox nut growers.

\section{Introduction}

The Indo-Gangetic Plains (IGP) is among the most extensive fluvial plains of the world and covers several states of the northern, central and eastern parts of India (Pal et al., 2009). EIGP being most important agricultural ecoregions, occupies 19.01 million ha net sown area and produces about $40 \%$ of total food grains of India (Bhatt et al., 2011). The region is thickly populated with 2.26- fold higher population density than the national average (Bhatt et al., 2013). Crop-livestock mixed farming is mainstay of economy in EIGP. However, landholdings are fragmented with a size of 0.86 and 0.47 ha, respectively, in lower and middle Gangetic plains as against national average of 1.15 ha (Bhatt, 2016). The region receives high annual precipitation (1200 to $1600 \mathrm{~mm}$ ) and occupies large no. of water bodies in the form of lakes, beels, ox bow lakes, ponds. Of the total area of 4.05 million ha area under diverse water ecologies in EIGP, more than 0.452 million ha is under shallow earthen ponds and tanks and most of them are exclusively used for cultivation of Fox nut (Euryale ferox Salisb), an aquatic promising food crop by resource poor farmers (Bhatt et al., 2011). 
Euryale ferox Salisb, belonging to family Nympheaceae, is grown in stagnant perennial water bodies.It has been classified as an annual aquatic herb with gigantic floating leaves, emergent macrophyte of monotypic genus, growing in the littoral parts of the flood plain wetlands of stagnated water bodies of 1.5-2.0 m depth (Kumar et al., 2011b). This aquaphyte grows with a rhizomatous stem deeply rooted in sediments of mud by fleshy and thick root clusters. Its seeds are also known as black diamond. Popped seeds are known as Makhana (Mandal et al. 2010). Fox nut is considered as a native of South-East Asia and China, but distributed to almost every parts of the world. In India, it is distributed in West Bengal, Bihar, Manipur, Tripura, Assam, Jammu and Kashmir, Eastern Orissa, Madhya Pradesh, Rajasthan and Uttar Pradesh. However, its commercial cultivation is limited only in EIGP besides some parts of Madhya Pradesh. Keeping in view its importance in livelihood security of more than 2.0 million resource poor farmers and shrinking water bodies, an attempt was made to find out alternative methods of fox nut cultivation besides improving productivity and profitability of fox nut growing communities.

\section{Materials and Methods}

Healthy fox nut seeds were sown in nursery beds in first week of December in each year of experimentation during 2012 to 2015. The experiment was conducted in 10 replications with a plot size of $25 \mathrm{~m}^{2}$ for each plot at experimental farm of the institute, located at Darbhanga, Bihar, India (latitude of $26.1119^{\circ}$ $\mathrm{N}$ and longitude of $\left.85.8960^{\circ} \mathrm{E}\right)$. Initial properties of a composite soil samples collected at the beginning of the field trial were silty clay loam (Inceptisol) with texture (sand $16 \%$, silt $62 \%$ and clay $24 \%$ ), crumb structure, bulk density $1.47 \mathrm{Mg} \mathrm{m}^{-3}$, particle density 2.51 , porosity $41.43 \%$, soil moisture retention capacity $38 \% \mathrm{w} / \mathrm{w}$ at field capacity and $20 \%$ at wilting point for 0.0 to $15.00 \mathrm{~cm}$ depth, Total N $0.025 \%$, P $0.012 \%$, K $0.201 \%$,

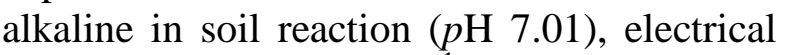
conductivity $\left(0.10 \mathrm{dS} \mathrm{m}^{-1}\right)$, cation exchange capacity $20 \mathrm{cmol} \mathrm{kg}^{-1}$, organic carbon $0.40 \%$, av. N $222 \mathrm{~kg} / \mathrm{ha}$, av. P $19.8 \mathrm{~kg} / \mathrm{ha}$, av. K 200 $\mathrm{kg} / \mathrm{ha}$, DTPA Fe $28 \mathrm{mg} / \mathrm{kg}$, Mn $10.70 \mathrm{mg} / \mathrm{kg}$, $\mathrm{Cu} \quad 1.60 \mathrm{mg} / \mathrm{kg}$ and $\mathrm{Zn} 0.30 \mathrm{mg} / \mathrm{kg}$. The chemical properties of irrigation water is $\mathrm{pH}$ 6.6, EC $0.00331 \mathrm{dS} \mathrm{m}-1$, alkalinity $80 \mathrm{mg} / \mathrm{l}$, total acidity $10 \mathrm{mg} / \mathrm{l}$, total hardness 12.80 $\mathrm{mg} / \mathrm{l}, \mathrm{Ca}$ hardness $7.45 \mathrm{mg} / \mathrm{l}, \mathrm{Mg}$ hardness $5.35 \mathrm{mg} / \mathrm{l}$, dissolved oxygen $6.0 \mathrm{mg} / \mathrm{l}$, inorganic $\mathrm{N} 400 \mathrm{ug} \mathrm{l}^{-1}$, inorganic P $5.55 \mathrm{mg} / \mathrm{l}$, $\mathrm{Ca} 2.12 \mathrm{mg} / \mathrm{l}, \mathrm{Mg} 0.70 \mathrm{mg} / \mathrm{l}$, Chloride $\left(\mathrm{Cl}^{-1}\right)$ 7.20 ppm, Fe 55 ug $1^{-1}$, Mn 80 ug l $^{-1}$, Cu 22 ug $\mathrm{I}^{-1}$ and $\mathrm{Zn} 40 \mathrm{ug}^{-1}$. The water depth of $0.3 \mathrm{~m}$ was maintained in each nursery beds and line sowing was followed by maintaining a spacing of $0.25 \mathrm{~m} \times 0.25 \mathrm{~m}$ from seed to seed and row to row. The fertilizer was applied at the rate of 100: 60: $40 \mathrm{~kg}$ of $\mathrm{N}, \mathrm{P}$ and $\mathrm{K}$, respectively, in the nursery beds. The germination took place by the end of February.

One month old seedlings were transplanted in last week of March in a plot size of $40 \mathrm{~m}^{2}$, accommodating 25 plants in each replication, at a spacing of $1.25 \mathrm{~m} \times 1.25 \mathrm{~m}$. A total of 20 plots were maintained in each replication. Line sowing was followed and fertilizer was applied at the rate of 100:60: $40 \mathrm{~kg}$ of NPK besides $15 \mathrm{t} / \mathrm{ha}$ of farmyard manure. The plant population in improved method of cultivation range from 6000-6400 nos/ha (Kumar et al., 2014). The flowering took place after 35-40 days of transplanting and the fruiting starts after 40-45 days of flowering. The crop was harvested in first week of August. This agro technique of fox nut cultivation was also compared with traditional methods of cultivation, i.e., cultivation in stagnant water bodies. The comparative data for various operations under pond methods of cultivation and field system is given below. 


\begin{tabular}{|c|c|c|}
\hline Parameter(s) & $\begin{array}{l}\text { Traditional Method of } \\
\text { Cultivation }\end{array}$ & Cropping System Mode \\
\hline Water requirement & $15000-20000 \mathrm{~m}^{3}$ & $3000-4000 \mathrm{~m}^{3}$ \\
\hline Seed requirement & $80-90 \mathrm{~kg} / \mathrm{ha}$ & $20 \mathrm{~kg} / \mathrm{ha}$ \\
\hline Source of water & Perennial water bodies & Irrigation water \\
\hline $\begin{array}{l}\text { Fertilizers and } \\
\text { manure }\end{array}$ & Not applied & $\begin{array}{l}\text { Applied before and } \\
\text { transplanting of seedlings }\end{array}$ \\
\hline Weed management & Tedious and time consuming & Easy and faster \\
\hline Plant population/ha & $5000-5500$ nos. & 6000-6400 nos. \\
\hline Seed yield & $1.6-2.0 \mathrm{t} / \mathrm{ha}$ & $2.8-3.0 \mathrm{t} / \mathrm{ha}$ \\
\hline $\begin{array}{l}\text { Cultivation of other } \\
\text { crops }\end{array}$ & $\begin{array}{l}\text { Not practiced except fish rearing } \\
\text { in some fox nut growing water } \\
\text { bodies }\end{array}$ & $\begin{array}{l}\text { After harvest of fox nut, water chest } \\
\text { nut, green fodder and/or pulses } \\
\text { (lentil) is grown. }\end{array}$ \\
\hline Harvesting & $\begin{array}{l}\text { Very tedious. Carried out only } \\
\text { by trained manpower }\end{array}$ & $\begin{array}{l}\text { Easy. Carried out even by unskilled } \\
\text { manpower. }\end{array}$ \\
\hline $\begin{array}{l}\text { Scope of horizontal } \\
\text { expansion of } \\
\text { Makhana cultivation }\end{array}$ & $\begin{array}{l}\text { Limited. It would depend upon } \\
\text { the availability of natural water } \\
\text { bodies. }\end{array}$ & $\begin{array}{l}\text { Wide scope with scope of expansion } \\
\text { in an area of } 1.0 \mathrm{~m} \text { ha. }\end{array}$ \\
\hline
\end{tabular}

The nutritional profile of popped nuts was carried out following the standard procedure (AOAC, 1995). Carbohydrates and calorific values were calculated following the methodology suggested by Gopalana et al., (1978). In case of post-harvest handling, data have been documented by surveying the local communities engaged in its grading, roasting and popping (Kumar et al., 2011a). Economic efficiency of fox nut cultivation was worked out following the methods suggested by Kumar et al., (2011b).

\section{Results and Discussion}

\section{Cultivation}

In conventional mode of fox nut cultivation, $80-90 \mathrm{~kg} / \mathrm{ha}$ of seeds are spread on the surface of standing water bodies in first year of cultivation. Seed sowing is not required in the subsequent years because left over seeds of the previous crop serves as a planting material during next year. Seed germination starts after 35-40 days of sowing in December-January and by the end of February and beginning of March, plantlets come out to the upper surface of the water. At this stage, an optimum distance of $1 \times 1$ meter from row to row and plant to plant is maintained by thinning of extra plants. The bright purple and solitary flowers start to appear in unsynchronized manners after 2 months of growth.

Flowering takes place after 35-40 days of transplanting, and the fruits get matured after 35-40 days of flowering and starts bursting. The seeds emerged after bursting of fruit float on the surface of water and after 2-3 days they start to settle down in the bottom of pond. No. of seeds showed a wide range of 36.0 to 190.0 per fruit with a seed yield 17.5 to $145.6 \mathrm{~g}$. Matured nuts are collected manually from bottom of the ponds through sweeping the area. It requires special skill and hence operated only by skilled manpower. In cropping system mode of cultivation, water depth of $0.30-0.40 \mathrm{~m}$ is maintained in agricultural fields (Kumar et al., 2011a). This method is easy to operate and provides opportunities for cultivation of subsequent crops in the same field. 


\section{Crop productivity}

Different cultivation practices were studied and compared for system productivity and net monetary gains. Compared to average productivity of $2.85 \pm 0.45 \mathrm{t} / \mathrm{ha}$ of nut in field method of cultivation, traditional system was able to yield only $1.60 \pm 0.21$ t/ha. By managing $10 \%$ area for rearing of Indian Major Carps (Rohu- Labeo rohita, CatlaCatla catla and Mrigal- C. mrigala), average fish productivity was recorded as $0.27 \pm 0.06$ t/ha with a stocking density of 5000 fingerlings/ha. However, in many traditional fox nut growing water bodies, self recruited wild fish species (Puntius spp., Mystis spp., Anabas spp. etc.) are found with a productivity of $0.11 \pm 0.01 \mathrm{t} / \mathrm{ha}$.

Water chest nut, as a tertiary crop, is harvested in four pickings from November to mid-December with the average productivity of $18.50 \pm 2.31 \mathrm{t} / \mathrm{ha}$. Green fodder yield of Berseem (Trifolium alexandrium) crop was recorded as $43.56 \pm 2.11$ t/ha after harvest of fox nut. Likewise, average productivity of lentil was estimated to be $1.12 \pm 0.21 \mathrm{t} / \mathrm{ha}$. The data indicated that improved methods of fox nut cultivation not only improved the system productivity but also contributed to net monetary gains. On average, net savings were two folds higher with the cultivation of secondary or tertiary crop in fox nut growing fields (Table 1).

\section{Post harvest handling}

In general, the resource poor fisherman communities carry out its processing and following steps are involved in processing of fox nut.

\section{Sun drying}

Fresh seeds are dried for 2-3 hrs in bright sun light to reduce the moisture content to an extent of 25\% (w.b.). From processing point of view, the optimum level of sun drying of the seeds is an important aspect.

\section{Grading}

Seven numbers of wooden framed sieves of different sizes are used for seed grading with the highest pore size of $12 \mathrm{~mm}$ dia. and lowest of $4 \mathrm{~mm}$ diameter, respectively. Seed grading is essentially required for uniform heating and popping.

\section{Pre-heating}

Sun dried seeds are heated in earthen pitcher or cast iron pan by placing them over the fire and stirring them continuously. Firewood and seed coat of fox nut is used as a source of energy and the time taken in heating is solely determined by the experience of the farmers engaged in this profession. However, the surface temperature of the pan is recorded above $250^{\circ} \mathrm{C}$ for heating of seeds. In general, 6 to $6.30 \mathrm{hrs}$ are required for pre-heating a $\mathrm{kg}$ of seeds (personal observations of authors).

\section{Tempering}

The storage of pre-heated seeds for duration of 48-72 hrs at the ambient condition is known as the tempering of the seeds. It is done purposefully to loosen the kernels within hard seed coat and helping the equilibrization of the moisture within the seeds (Verma et al., 2010).

\section{Roasting and popping}

About 200-250g of pre-heated and tempered seeds are roasted in a cast iron pan in a single layer over the fire at $300^{\circ} \mathrm{C}$ surface temperature with continuous stirring for 2 minutes. About 8-10 nos. of roasted seeds are scooped out quickly from the pan and placed on a hard wooden surface and the roasted seeds are cracked with the help of wooden 
hammer within fraction of seconds. As soon as the hard shell of the seeds break, the kernels pop comes out in the expended form of fox nut. On average, $100 \mathrm{~kg}$ of seed yield $38-40 \mathrm{~kg}$ of popped nuts (Bhatt et al., 2012).

\section{Polishing and packaging}

Thin red colour membranous which remains attached to popped fox nut is removed through rubbing in bamboo baskets. This operation facilitates more whiteness and lustre to fox nut and carried out immediately after popping before it absorbs moisture. The crop is less perishable and packed in gunny bags with polythene lining. One gunny bag could accommodate $7.5-8.0 \mathrm{~kg}$ of popped nuts and stored at room temperature.

\section{Production}

India is the only country where makhana is commercially cultivated. Within India, it is mainly cultivated in water surplus ecologies of EIGP. About 2.0 million resource poor farmers are associated with its cultivation. Edible delicacy of popped fox nut is well established. A $\mathrm{kg}$ of popped nuts cost about US\$ 4.5-6.0 in domestic markets depending on the quality. However, the crop is largely exported to other Asian countries.

Table.1 Productivity and monetary gains of fox nut cultivation in EIGP

\begin{tabular}{|l|l|l|l|}
\hline $\begin{array}{l}\text { Cultivation } \\
\text { practices }\end{array}$ & Crop/cropping systems & $\begin{array}{l}\text { System } \\
\text { productivity (t/ha) }\end{array}$ & $\begin{array}{l}\text { Net monetary } \\
\text { gains (US\$/ha) }\end{array}$ \\
\hline \multirow{2}{*}{$\begin{array}{l}\text { Traditional } \\
\text { method(s) }\end{array}$} & Fox nut as a sole crop & $1.60 \pm 0.21$ & 734.0 \\
\cline { 2 - 4 } $\begin{array}{l}\text { Improved } \\
\text { method(s) }\end{array}$ & Fox nut and fish rearing & $1.86 \pm 0.23$ & 809.75 \\
\hline & $\begin{array}{l}\text { Integration of fox nut with fish, } \\
\text { followed by water chestnut }\end{array}$ & $22.86 \pm 1.23$ & 1894.60 \\
\cline { 2 - 4 } & Fox nut followed by green fodder & $45.60 \pm 2.11$ & 1641.90 \\
\cline { 2 - 4 } & Fox nut followed by wheat & $5.86 \pm 0.36$ & 1714.56 \\
\cline { 2 - 4 } & Fox nut followed by lentil & $3.80 \pm 0.21$ & 1778.56 \\
\hline
\end{tabular}

Table.2 Nutritive value of popped fox nut

\begin{tabular}{|c|c|c|}
\hline Sl. No. & Parameters & Values \\
\hline 1 & Total ash* $^{*}$ & $0.40 \pm 0.03$ \\
\hline 2 & Fat $^{*}$ & $0.50 \pm 0.05$ \\
\hline 3 & Protein* $^{*}$ & $8.70 \pm 0.23$ \\
\hline 4 & Carbohydrate* $^{*}$ & $79.80 \pm 2.13$ \\
\hline 5 & Energy $(\mathrm{MJ} / \mathrm{kg})$ & $14.98 \pm 0.16$ \\
\hline 6 & Phosphorus $(\mathrm{mg} / 100 \mathrm{~g})$ & $53.20 \pm 0.26$ \\
\hline 7 & Potassium $(\mathrm{mg} / 100 \mathrm{~g})$ & $42.0 \pm 0.13$ \\
\hline 8 & Iron $(\mathrm{mg} / 100 \mathrm{~g})$ & $1.40 \pm 0.09$ \\
\hline 9 & Calcium $(\mathrm{mg} / 100 \mathrm{~g})$ & $18.50 \pm 0.08$ \\
\hline 10 & Magnesium $(\mathrm{mg} / 100 \mathrm{~g})$ & $13.90 \pm 0.03$ \\
\hline 11 & Sodium $(\mathrm{mg} / 100 \mathrm{~g})$ & $71.00 \pm 1.13$ \\
\hline 12 & Copper $(\mathrm{mg} / 100 \mathrm{~g})$ & $0.50 \pm 0.02$ \\
\hline 13 & Manganese $(\mathrm{mg} / 100 \mathrm{~g})$ & $1.30 \pm 0.01$ \\
\hline 14 & Zinc $(\mathrm{mg} / 100 \mathrm{~g})$ & $1.10 \pm 0.01$ \\
\hline
\end{tabular}

*Per cent by weight 
Table.3 Amino acid composition in popped fox nut

\begin{tabular}{|l|l|l|}
\hline Sl. No. & \multicolumn{1}{|c|}{ Parameters } & \multicolumn{1}{|c|}{$\begin{array}{c}\text { Values } \\
(\mathrm{g} / 100 \mathrm{~g} \text { protein })\end{array}$} \\
\hline 1 & Aspartic acid* & $7.71 \pm 0.21$ \\
\hline 2 & Glutamic acid $* *$ & $17.91 \pm 0.57$ \\
\hline 3 & Serine & $5.42 \pm 0.27$ \\
\hline 4 & Glycine & $3.43 \pm 0.17$ \\
\hline 5 & Histidine & $2.72 \pm 0.28$ \\
\hline 6 & Arginine & $10.57 \pm 0.30$ \\
\hline 7 & Threonine & $3.71 \pm 0.21$ \\
\hline 8 & Alanine & $5.15 \pm 0.57$ \\
\hline 9 & Proline & $3.59 \pm 0.25$ \\
\hline 10 & Tyrosine & $0.45 \pm 0.12$ \\
\hline 11 & Valine & $9.19 \pm 0.26$ \\
\hline 12 & Methionine*** & $5.64 \pm 0.40$ \\
\hline 13 & Cysteine**** & $1.84 \pm 0.19$ \\
\hline 14 & Isoleucine & $5.14 \pm 0.10$ \\
\hline 15 & Leucine & $9.77 \pm 0.25$ \\
\hline 16 & Phenylalanine & $4.49 \pm 0.91$ \\
\hline 17 & Lysine & $3.36 \pm 0.48$ \\
\hline$*$ Includes both Aspartic acid and Asparagine \\
$* *$ Include both Glutamic acid and Glutamine \\
$* * *$ Estimated as Methionine Sulfone \\
$* * * *$ Estimated as Cysteic acid & \\
\hline
\end{tabular}

\section{Nutritive values of popped nuts}

Popped nuts are particularly rich in carbohydrates. However, protein and other nutrients are also comparable with most cereal crops. It also contains high amount of energy and low fat content (Table 2). Data on amino acid profiling indicated that popped nuts are highly rich in most of the essential aminoacids such as glutamic acid, followed by arginine, leucine, valine and aspartic acid (Table 3).

\section{Food items}

Popped nuts are used in the preparation of a number of delicious and rich dishes like kheer, vermicelli and halva etc. It is used in pudding and milk based sweets. Dal makhani and vegetable curries become delicious when Makhana is mixed for taste and thickening object. Roasted nuts mixed with salt and spices are served with tea/coffee as snacks. The tribal communities, however, harvest its mature fruits and use for vegetable purposes probably due to the fact that processing of fox nut is carried out only by skilled manpower in EIGP.

\section{Industrial uses}

Makhana seeds are very rich in carbohydrate content. From lusting point of view, the starch of popped seeds is of premium quality hence it is used for coating in the quality fabrics like Banarasi sarees and high quality cotton dresses. 


\section{Religious uses}

In every religion, Makhana is considered as the pious and divine food item. In Hindu religion, it is used in all the worshiping ceremonies, Hawan, Pooja etc. In addition to this, due to its heavenly nature, it is considered as the best offering to god and goddesses in temples.

The effective use of stagnant water bodies like ponds, land depressions, oxbow lakes, swamps and ditches is possible through fox nut cultivation. Its integration with fishes and water chestnut has been found one of the most viable farming system models in EIGP (Bhatt et al., 2012). Makhana cultivation in cropping system mode is a classical example, which offers unique opportunity to cultivate it at shallow water depth with optimum yield (Bhatt, 2016). After harvest of fox nut, water chestnut, green fodder and/or pulses could be successfully cultivated in the same field (Bhatt et al., 2013). Improved method of its cultivation provides the gainful employment besides food security to the farming families.

Since legal rights of land ownership rests with well-to-do farmers, who lease out land to landless farmers for fox nut cultivation, leasing policy need to be streamlined. It should be for a minimum of 5 yrs in order to sustain the livelihood of weaker section of farmers. Due to short term leasing of land (2$3 \mathrm{yrs}$ ), the fox nut growers are losing interest in cultivation of this potential crop (Personal observations of authors).

Though fox nut is a hardy crop, however, aphids (Rhopalosiphum nymphaeae L), caseworm (Elophila crisonalis W) and root borer (Donacia delesserti) damage the crop to some extent (Kumar et al., 2011a). Besides insects, leaf blight (Alternaria tenuis) also causes damage to healthy plants. Mechanization of makhana cultivation is need of the hour, keeping in view the fact that its traditional cultivation is labour intensive and very tedious and painstaking task. The resource poor fisherman communities are, by and large, associated with its cultivation. To promote its cultivation, we recommend credit facilities to resource poor farmers. Further, the partnership with different stake holders in supply chain and value addition at regional, national and international level will give new paradigm shift to this crop at global level.

Fox nut bran, a by-product of its processing, could be used as feed to poultry and livestock. It possesses $89.2 \%$ dry matter with $7.1 \%$ protein, $0.62 \%$ fat and $94.4 \%$ organic matterand supplement the concentrate feed requirement by 6 and 40\%, respectively, in rural poultry and livestock(Bhatt et al., 2012).

Foliage of fox nut is alternate, round, large with $1.0-1.5 \mathrm{~m}$ radius. The decomposition of leaves and other plant parts contribute, 34.4, $56.04,53.02$ and $1.83 \mathrm{~kg} / \mathrm{ha} / \mathrm{yr}$ of nitrogen, phosphorus, potassium and sulphur, respectively, into the soil (Singh et al., 2014). Since fertilizer is not used in traditional methods of cultivation, nutrients through litter decomposition serves the source of nutrients (personal observations of authors). Diversification in aquatic crops is need of the hour in order to improve upon the productivity and profitability to fox nut growers (Kumar et al., 2015). Sole crop of fox nut results into net monetary gains of US \$ 734.0 compared to US \$ 1333.0 in improved methods. Further, studies are, however, required on weed management in fox nut growing water bodies, integration of cat fish (Clerius batrichus); Murrels (Channa striatus and C. morlius), Anabas testeduneous, Ompak pabta and $O$. bimaculatus with fox nut; development of seed harvester, seed grader and popping machines to reduce the drudgery of fishermen community (Sarkar et al., 2015); harnessing 
the potential of waste water resources through makhana cultivation and relationship between seed size and seedling vigour.

\section{References}

AOAC., 1995. Official Methods of Analysis. 16th edn. Association of Official Analytical Chemists, Washington, D. C.

Bhatt, B.P., Haris, A. Abdul, Islam, Adlul; Dey, A., Mukherjee, J. Barari, S.K., Das, B., Kaushal, D.K. 2011. Agriculture in Eastern Region: Opportunities and Challenges. Technical Bulletin, ICAR Research Complex for Eastern Region, India, pp. 78.

Bhatt, B.P., Haris, A.A., Dey, A., Singh, K.M. 2012. Technological Options for Agricultural Transformation in Eastern Region. ICAR Research Complex for Eastern Region, Patna, India, pp. 99.

Bhatt, B.P., Sikka, A.K., Mukherjee, J., Islam, A., Dey, A. 2013. Status of Agricultural Development in Eastern Region. ICAR Research Complex for Eastern Region, Patna, India, pp. 519.

Bhatt, B.P. 2016. Production and technological gaps in middle Indo-Gangetic plains. Policy Document, ICAR Research Complex for Eastern Region, Patna, India, pp. 15.

Gopalan, C.B., Ramasastri, V.,Balasubramanian, S.C. 1978. Nutritive Value of Indian Foods. National Institute of Nutrition, Hyderabad, India.

Kumar, L.; Gupta, V.K.; Khan, M.A.; Singh S.S.; Jee, Janardan, Kumar, A., 2011a. Field based Makhana cultivation for improving cropping intensity of rice fields. Bihar Journal of Horticulture, 1(1):71-72.

Kumar, L., Gupta, V.K., Jha, B.K. Singh, I.S.; Bhatt, B.P., Singh, A.K. 2011b. Status of Makhana (Euryale ferox Salisb.) cultivation in India. Technical Bulletin No. R-32/PAT21, ICAR Research Complex for Eastern Region, Patna, India, pp. 31.

Kumar, L.; Gupta, V.K., Singh, I.S., Bhatt, B.P.,Kumar, Devendra, 2014. Sequential double cropping system of makhana (Euryale ferox Salisb.) cultivation in agricultural fields of North Bihar, India. Int. Journal of Agricult. Stat. Sci., 10(1): 105108.

Kumar, L., Choudhary, A.K.,Bhatt, B.P.,Singh, K.P. 2015. Genetic divergence in makhana (Euryale ferox Salisb.). Indian Journal of Horticulture, 72(3): 365-369.

Mandal, R.N. Saha, G.S., Sarangi, S. 2010. Harvest and processing of Makhana (Euryale ferox Salisb.)-An unique assemblage of traditional knowledge. Indian Journal of Traditional Knowledge, 9(4): 684-688.

Pal, D.K. Bhattacharyya, P. Srivastava, P. Chandran, P.Ray, S.K. 2009. Soils of the Indo-Gangetic plains: their historical perspective and management. Current Science 96:1193-1202.

Sarkar, B.Sundaram, P.K. Dey, A. Kumar, U. Sarma, K.,Bhatt, B.P. 2015. Traditional agricultural tools used by tribal farmers in eastern India. Research Journal of Agricultural Sciences, 6(1): 215-219.

Singh, I.S., Kumar, Lokendra, Singh, A.K.; Bhatt, B.P., Singh, S.P. 2014. Impact of makhana (Euryale ferox Salisb.) based cropping systems on nutrient dynamics of inceptisols of North Bihar. Int. Journal of Agricult. Stat. Sci., 10(1): 125-129.

Verma, A.K., Banerji, B.K. Chakraborty, D., Dutta, S.K. 2010. Studies on Makhana (Euryale ferox Salisb.). Current Science, 99(6):795-800.

\section{How to cite this article:}

Bhatt, B.P., V.K. Gupta, Lokendra Kumar, Indu Shekhar Singh and Bikash Sarkar. 2017. Euryale ferox (Salisb): Promising Aquatic Food Crop of Eastern Indo Gangetic Plains. Int.J.Curr.Microbiol.App.Sci. 6(6): 1914-1921. doi: https://doi.org/10.20546/ijcmas.2017.606.223 